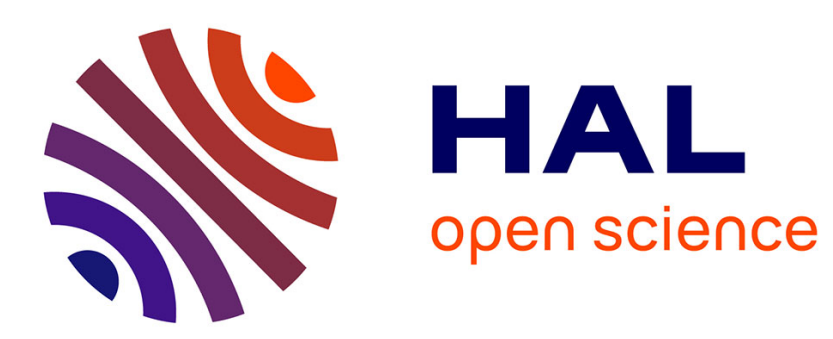

\title{
Coalbed methane producibility from the Mannville coals in Alberta, Canada: A comparison of two areas
}

T. Gentzis, F. Goodarzi, F.K. Cheung, Fatima Laggoun-Défarge

\section{To cite this version:}

T. Gentzis, F. Goodarzi, F.K. Cheung, Fatima Laggoun-Défarge. Coalbed methane producibility from the Mannville coals in Alberta, Canada: A comparison of two areas. International Journal of Coal Geology, 2008, 74 (3-4), pp.237-249. 10.1016/j.coal.2008.01.004 . insu-00258786

\section{HAL Id: insu-00258786 \\ https://hal-insu.archives-ouvertes.fr/insu-00258786}

Submitted on 28 Mar 2008

HAL is a multi-disciplinary open access archive for the deposit and dissemination of scientific research documents, whether they are published or not. The documents may come from teaching and research institutions in France or abroad, or from public or private research centers.
L'archive ouverte pluridisciplinaire HAL, est destinée au dépôt et à la diffusion de documents scientifiques de niveau recherche, publiés ou non, émanant des établissements d'enseignement et de recherche français ou étrangers, des laboratoires publics ou privés. 


\title{
Coalbed methane producibility from the Mannville coals in Alberta, Canada: A comparison of two areas
}

\author{
T. Gentzis ${ }^{a}$, F. Goodarzi ${ }^{b}$, F.K. Cheung ${ }^{b}$ and F. Laggoun-Défarge ${ }^{c}$ \\ ${ }^{a}$ Petron Resources, L.P. 3000 Internet Boulevard, Suite 400, Frisco, TX 75034, USA \\ ${ }^{\mathrm{b}}$ Geological Survey of Canada, 3303-33rd Street, Calgary, Canada AB T2L 2A7 \\ ${ }^{c}$ Institut des Sciences de la Terre d'Orléans, UMR 6113-CNRS/Univ. Orléans, BP 6759, \\ 45067 Orléans Cedex 2, France
}

\begin{abstract}
The Mannville coals in the Fenn area, Alberta Plains, have desorbed gas content averaging $8.57 \mathrm{~cm}^{3} / \mathrm{g}(275 \mathrm{scf} / \mathrm{t})$, which is similar to the same coals in the Corbett Creek area, almost $400 \mathrm{~km}$ away. Vitrinite reflectance values are also similar, although the coals at Corbett Creek are situated about $300 \mathrm{~m}$ shallower, which points to a rank excursion from Hilt's burial law curves at Corbett Creek. Coals from both areas are within the "oil window". The Medicine River Seam in the Fenn area has higher total inertinite content and greater proportions of inertodetrinite and detrovitrinite, suggesting that peat deposition occurred in swamps and marshes and were prone to periodic flooding. At Corbett Creek, the Mannville coal seams are characterized by greater concentrations of telo-inertinite, which contributes to coal mesoporosity and the potential for free gas storage in the open cell lumens, and to an increased gas flow along lithotype boundaries (horizontal permeability). Non-fluorescing vitrinite was present mostly in the Upper Medicine River Seam, which was deposited in a regressive environment. The Lower Medicine River Seam, which formed during a marine transgressive phase, contained greater amounts of fluorescing vitrinite. The Mannville coals in the Fenn area are moderately under-pressured in relation to those at Corbett Creek, which may have an impact on gas retention capacity. The difference in absolute coal permeability $(1-3.5 \mathrm{mD}$ at Fenn versus 3-4 $\mathrm{mD}$ at Corbett Creek), which is likely the result of higher in-situ stresses in the deeper Mannville coals at Fenn, has had an effect on both gas and water production rates from these coals. However, the largest impact on gas production volumes has been made by the application of horizontal drilling technology, initially at Fenn, and more recently by multiple horizontal wells drilled at Corbett Creek.
\end{abstract}

Keywords: Coalbed methane; Mannville coals; Alberta; Petrology; Permeability; Horizontal wells

\section{Introduction}

The Western Canada Sedimentary Basin (WCSB) (Fig. 1) contains large volumes of coal. The Canadian Gas Potential Committee estimates that CBM in-place resources are about 14 trillion $\mathrm{m}^{3}$ (about $500 \mathrm{TCF}$ ), 75\% of which is located in Alberta (National Energy Board Report, 2006; www.neb-one.gc.ca/energy/EnergyReports/EMAGasTDeliverabilityCanada2006_2008_e.pdf). The Energy Resources Conservation Board (ERCB) of Alberta [formerly known as the 
Alberta Energy and Utilities Board (AEUB)] reports the Alberta NGC resource potential to be $500 \mathrm{TCF}, 64 \%$ (320 TCF) of which is estimated to be in the Lower Cretaceous Mannville Formation coals (ERCB Report ST98-2006; http://www.ercb.ca/docs/products/STs/st982006.pdf). In addition, the Upper Cretaceous Horseshoe Canyon (HSC) Formation coals may contain 71 TCF of methane, the Belly River Formation coals 147 TCF, and the Ardley Formation coals about 57 TCF (ERCB Report ST98-2006; http://www.ercb.ca/docs/products/STs/st98-2006.pdf). The recoverable amount of CBM remains unknown although some experts believe that 20 to 100 TCF could ultimately be recovered. CBM production in Western Canada was estimated to be 4.5 million $\mathrm{m}^{3} / \mathrm{D}$ (160 MMCF/D) (million cubic feet per day) at the end of 2004, representing less than 1\% of the total Canadian natural gas production. Publicly available data indicates that only $240,000 \mathrm{~m}^{3} / \mathrm{D}(8.5 \mathrm{MMCF} / \mathrm{D})$ was produced from the Mannville Formation coals in 2006.

\subsection{Historical CBM production from the Mannville coals in two areas in Alberta}

The history of Mannville CBM development in Alberta has evolved from vertical fracturestimulated wells to single horizontals and then to multiple horizontal wells. In the mid-1990s, the Mannville coal seams at Fenn-Big Valley (refer to as Fenn in Fig. 2) were fracture stimulated by Gulf Canada Resources. Initial gas rates from vertical wells ranged from 20,000 to $28,000 \mathrm{~m}^{3} / \mathrm{D}(0.7$ to $1.0 \mathrm{MMCF} / \mathrm{D})$ but declined within 2-3 days and stabilized at 563 to $1690 \mathrm{~m}^{3} / \mathrm{D}(20-60 \mathrm{MCF} / \mathrm{D})$. Produced water rates were only $1-2 \mathrm{BW} / \mathrm{D}$, an indication that the coals in this area are "dry", possibly because of low permeability. In 2002-2004, Trident Exploration Corp. and its partner Nexen Inc. drilled almost 100 vertical CBM wells in the Corbett Creek area (Fig. 2). A typical vertical Mannville well produced $1127 \mathrm{~m}^{3} / \mathrm{D}$ (40 MCF/D), and a good vertical well about $5633 \mathrm{~m}^{3} / \mathrm{D}$ (200 MCF/D) (Simpson, 2005). Recovery rates from vertical wells were low and ranged from $21-38 \%$. Produced water volume was high, about $250 \mathrm{BW} / \mathrm{D}$ during the first 3-4 months of production, a clear indication that the Mannville Formation coals at Corbett Creek are not only "wet" but also possess reasonable permeability. Public data from the Alberta EUB show that more than 100 horizontal Mannville wells were drilled in 2005-2006, the vast majority in the Corbett Creek area. Three horizontals drilled in one section of land (640 acres) had combined production of $76,000 \mathrm{~m}^{3} / \mathrm{D}(2.7 \mathrm{MMCF} / \mathrm{D})$, while eleven horizontals drilled in a radial (spoke) pattern over 4 sections of land had total production of over 140,000 m³ $/ \mathrm{D}(5 \mathrm{MMCF} / \mathrm{D})$. Horizontal wells shortened the dewatering period at Corbett Creek to four months. CDX Canada, Co. drilled a horizontal CBM well in the Medicine River coal seam of the Mannville Group in the Oberlin area (Fig. 2), located very close to Fenn. The well has been producing an average of $28,000 \mathrm{~m}^{3} / \mathrm{D}(1 \mathrm{MMCF} / \mathrm{D})$ since April 2004. This well became the first commercial horizontal CBM well in the deep (> $1300 \mathrm{~m})$ and low permeability Mannville coals.

Unlocking the Mannville CBM has been a priority because of the high GIP (gas-in-place) potential in these coals, which ranges from 4-10 BCF/section based on coal thickness and gas content. The main challenge has been the low permeability of the coals as a result of burial depth and high in-situ stresses. The objective of this study is to compare and contrast two widely separated areas in the Alberta Basin (Fenn and Corbett Creek), which have recently experienced commercial CBM development in the Mannville coals, primarily as a result of the application - and perfection - of horizontal drilling technology. The importance of organic petrology, coal rank and type on gas content, and the influence of stress regime and permeability on gas producibility from the Mannville coals will be highlighted. 


\section{Methods}

Core taken from the Lower Cretaceous Mannville Group at two geographic areas in the Alberta Plains was studied in detail. The cores were stored at the Alberta EUB Core Repository. Particular emphasis was given to the coals, which were described macroscopically for lithotype and cleat development. Selected coals were processed at the Geological Survey of Canada laboratory in Calgary for rank (vitrinite reflectance; 50 points), maceral composition ( 500 points) using standardized methods of sample preparation and microscopic analysis. Proximate analysis was also conducted by a commercial laboratory in Calgary.

Macroscopic composition of a seam's profile reflects the depositional history and microcomposition but also aids in seam correlations. Maceral analysis can be distinctive for seams and help with the interpretation of depositional environment. Both the macroscopic and microscopic coal analysis can be correlated with gas generation and storage capacity as well as with cleat development and permeability.

\section{Results and discussion}

\subsection{Regional setting}

\subsubsection{Stratigraphy and sedimentation}

Using data taken from 50 cores, Wadsworth et al. (2002) studied, in great detail, the stratigraphic style and accommodation setting of the Mannville coals in south-central Alberta, including the Fenn area. Their study revealed a number of features that are characteristic of intermediate accommodation in non-marine strata, including coals. The Mannville stratigraphy in the Fenn area is characterized by incised valleys and interfluves. The incised valleys correlate laterally with the coals, which suggests that the coal seams contain sequence boundaries that span relative sea level cycles (Wadsworth et al., 2002). A feature that is common to the Mannville coals in the Fenn area is seam splitting, in areas away from paleotopographic highs that reflect the development of Paleozoic reef mounts. Thus, it is likely that Mannville coal seam thickness is controlled partially by differential subsidence. The Mannville Group coals, including the Medicine River Seam, comprise a number of wetting- and drying-upward cycles that represent repeated events of peat accumulation under rising or falling accommodation cycles, with or without any hiatus between the cycles. Changes in groundwater levels linked to sea level changes were responsible for these cycles (Wadsworth et al., 2002).

Banerjee and Kalkreuth (2002) determined the petrographic composition of the amalgamated Medicine River Seam from a nearby well (7-1-37-21W4) (Lat $52^{\circ} 2^{\prime} \mathrm{N}$ and Long $113^{\circ} 0^{\prime} \mathrm{W}$ ) at depths of 1352-1364.5 m using automated image analysis. No vitrinite reflectance data were reported. This well was drilled on a structural basement high. Basinward or downdip from the well, the seam splits into an upper and lower leaves, separated by a shale parting. The lower leaf is transgressive and the upper leaf is regressive, thus the split represents a single TR (transgression-regression) cycle. The Lower Medicine River Seam (LMR) is at the base of a progradational 3rd-order sequence (Banerjee and Kalkreuth, 2002). The full seam contains $58.6 \%$ vitrinite and $30.8 \%$ inertinite. Variations were noted in the upper and lower leaves of the Medicine River Seam, reflecting the transgressive or regressive character of the seam. During regressive phases of peat accumulation, vitrinite contents decrease at the expense of 
inertinite. The fluorescing intensity of the vitrinite also decreases and the vitrinite reflectance increases. During transgressive cycle phases, vitrinite becomes the predominant organic component ([Banerjee et al., 1994] and [Banerjee and Kalkreuth, 2002]).

An increase in the relative amounts of vitrinite and high TPI (tissue preservation index) values in the lower part of the Medicine River Seam seen by Banerjee and Kalkreuth (2002) suggest a wetting-upward cycle, autochthonous peat accumulation, and balanced accommodation rate/peat production rate in a raised mire. Increasing dispersed sporinite and inertinite (mainly as inertodetrinite) and the presence of fusain layers in the upper part of the Medicine River Seam, suggest instability in the rate of accommodation, a change to limnotelmatic peat accumulation or a wetting-upward cycle (as expressed by high GWI values) and the formation of dull coal through the accumulation of mainly allochthonous peat components.

\subsubsection{Structural geology}

The entire Mannville sequence in the east-central Alberta Plains is pervaded by linear features, which extend from the pre-Mesozoic unconformity to the top of the Colorado Group that overlies the Mannville Group. These high-angle fractures, termed "linears", are interpreted to represent faults and joint zones, and appear to be associated with basement magnetic anomaly lineaments (Gregor, 1997). These linears or master fractures most likely have played a significant role in controlling the subsurface fluid flow, have acted as zones of enhanced permeability or as barriers to permeability depending on their orientation, and also have controlled the post-Mannville structural development (Gregor, 1997). The differential subsidence seen during the time of Mannville coal formation is attributed to fault reactivation on the underlying Paleozoic basement. "Basement control" has been used to explain a variety of anomalous features in the basin, such as orientation of reef trends, abrupt facies changes, development of fracture porosity, and accumulation of hydrocarbons (Ross and Eaton, 1999). Maps of inferred fault planes indicate a horst and graben style of extensional faulting (Wadsworth et al., 2002). Fault planes appear to be associated with relatively steeply dipping basement topography. With few exceptions, the orientations of faults do not appear to coincide with underlying basement structures (Ross and Eaton, 1999). Areas that contain the thickest cumulative Mannville coal preferentially occur above horst blocks. Underlying structures and paleotopography likely exerted a strong influence on sedimentation patterns in intermediate accommodation settings, because the rates of vertical accretion were insufficient to suppress the effects of differential subsidence (Wadsworth et al., 2002).

\subsubsection{Coal grade, type and rank}

The rank and type of coal influence the volume of thermogenic gas that has been generated, the capacity of the coal to retain that gas, the development of natural fractures (cleats) that are the main permeability pathways, and the geomechanical properties and response to stimulation processes. The Mannville coals are humic coals, are finely banded at a macroscopic level, and have formed from rooted vegetation that was deposited in-situ in mires and accumulated as peat. These coals were deposited in a fluvio-deltaic setting, which was characterized by widespread coal distribution, the formation of few, but thick, seams that have low ash content, the presence of splits that are syn-sedimentary and tectonic in nature, and divergent seams that have higher ash content.

The Medicine River Seam in the Fenn area typically contains intervals that have low ash content (< 10 wt.\%; dry basis), with some values being in the $3-5 \mathrm{wt} . \%(\mathrm{db})$ range. The 
Upper Mannville Seam has higher ash content, typically 15-18 wt.\% (db). A composite sample was taken from the Upper Medicine River Seam (UMR) at 1258.8-1263.1 $\mathrm{m}$ in well 5-23-36-20W4 in the Fenn area. Maximum vitrinite reflectance of two coal samples from the above well was $0.51 \%$ and $0.54 \%$ indicating high volatile $\mathrm{C}$ bituminous rank. In the Oberlin 5-10-38-21W4 well, two coal samples were analyzed for reflectance and maceral composition. Maximum reflectance was $0.66 \%$ at $1307.8 \mathrm{~m}$ (upper leaf, Medicine River Seam) and $0.71 \%$ at $1316 \mathrm{~m}$ (lower leaf, Medicine River Seam). Other coals examined macroscopically from the Fenn area showed a greater proportion of dull-banded coal (dull clarain), dull coal (durain), and massive vitrain (Fig. 3A) having well-developed face cleats (FC; 1-1.5 cm apart) and poorly developed butt cleats (BC; 3-4 cm apart) (Fig. 3B).

The most important coal seam in the Corbett Creek area (referred to as the Main Seam) is $>4 \mathrm{~m}$ thick. A thinner coal seam $(1.5-2 \mathrm{~m})$ is located beneath the main seam, resulting in a cumulative thickness of $>6 \mathrm{~m}$. Other thinner coals are also present in the area. Core analysis shows that the Mannville coals at Corbett Creek consist of bright (vitrain) and bright-banded (bright clarain) lithotypes (Fig. 4A) with well-developed, closely-spaced $(0.5 \mathrm{~cm})$ face cleats (FC; Fig. 4B). Some coal cleats were filled with siderite, but generally no calcite or bitumen was present in the cleats. Vitrinite reflectance was $0.62 \%$ at $1090-1095 \mathrm{~m}$ and slightly higher $(0.67 \%)$ at $980-990 \mathrm{~m}$ in a nearby well (6-24-61-6W5). Vitrinite reflectance values are similar to those at Fenn although the coals at Corbett Creek are situated about $300 \mathrm{~m}$ shallower. This suggests a vitrinite reflectance anomaly or excursion in the Corbett Creek area from Hilt's burial law (Stasiuk et al., 2002). The higher maturity may be the result of higher heat flow during burial at Corbett Creek compared to the Fenn area. This, in turn, may have contributed to the higher gas content of the Mannville coals in the Corbett Creek area, as will be shown later.

\subsection{Coal petrology}

\subsubsection{Maceral composition}

A composite sample was taken from the Upper Medicine River Seam (UMR) at 1258.8$1263.1 \mathrm{~m}$ in well 5-23-36-20W4, Fenn area. The sample contained a moderate percentage of inertinite $(35.8 \%)$ and vitrinite $(62.8 \%)$ macerals, of which $4.8 \%$ was pseudovitrinite. Parts of the vitrinite matrix were weakly to strongly fluorescing with a brown colour, whereas oval fresh and weathered resinite bodies embedded in vitrinite cell structures were fluorescing strongly to weakly (Fig. 5A to C). Inertodetrinite was the dominant inertinite maceral. Liptinite made up only $1.4 \%$, split almost equally between resinite and sporinite with the remainder being liptodetrinite (Fig. 5D). Exsudatinite filled microcracks and fissures in the vitrinite. Weakly fluorescing corpocollinite was also present. Mineral matter consisted predominantly of clays with trace amounts of pyrite.

In the Oberlin 5-10-38-21W4 well, two coal samples were analyzed for reflectance and maceral composition. Vitrinite consisted of collotelinite A and B bands showing faint cell structure (Fig. 6A) and oval corpogelinite (Fig. 6B). Vitrinite content was 53.6\% and 58.8\%. Weakly fluorescing resin bodies infilled cells in the vitrinite. Microcracks in the vitrinite were filled with exsudatinite. Inertinite content was $29.2 \%$ and $37.8 \%$, made up of equal proportions of semifusinite and fusinite, followed by macrinite and micrinite in a trimacerite matrix (Fig. 6C and D). Liptinite varied from 5.2-8.8\% and mineral matter was less than 
$3.2 \%$. Further north, in well 10-25-40-25W4, Banerjee and Kalkreuth (2002) performed a detailed maceral composition analysis of lithologies in the LMR seam (upper leaf) that ranged from bright, bright banded, banded, dull banded, and dull. The average vitrinite content was $47.8 \%$ and average inertinite was $51.0 \%$. The highest vitrinite content was observed in the lower part of the seam. In a nearby well located at 6-7-40-24W4, the upper leaf in the LMR seam averaged $25 \%$ vitrinite and $68 \%$ inertinite. Many samples analyzed were rich in detrital components (vitro- and inertodetrinite) suggesting severe degradation of the plant material. The Medicine River Seam in the Fenn area contained a high percentage of inertinite, inertodetrinite, sporinite and detrovitrinite.

The Mannville coals in well 2-21-60-6W5 at $1095 \mathrm{~m}$ depth, Corbett Creek area, contained massive collotelinite showing cell structure (Fig. 7A and B). Inertinite was mainly in the form of telo-inertinite (Fig. 7C and D), manifested as layers or lenses parallel to bedding that contribute to lateral (horizontal) permeability along the lithotype interface. Telo-inertinite with open (un-mineralized) cell lumens present in the Mannville coals at Corbett has the ability to store fee gas and to enhance coal meso-porosity (phyteral porosity). Telo-inertinite is not physically or geochemically altered by diagenesis or catagenesis. Desorption rates can be greater in inertinite-rich coal suggesting that inertinite contributes significantly to the mesopore system (Crosdale et al., 1998). Inertodetrinite and detrovitrinite were less commonly present in the coals examined. Cell lumens were impregnated by resin and showed weak fluorescence. Bands of collodetrinite contained abundant liptinites, in the form of cutinite, resinite, sporinite, and exsudatinite.

\subsubsection{Adsorption isotherms}

Two adsorption isotherms of coals from the Medicine River Seam, Oberlin 5-10-38-21W4 well (Fig. 8A and B) were conducted at a reservoir temperature of $51^{\circ} \mathrm{C}$ using high-pressure methane. The coal in this well is moderately under-pressured at $1407 \mathrm{psi}(9.7 \mathrm{MPa})$. The coal from the upper leaf at $1307.8 \mathrm{~m}$ (ash of $9.2 \%$, equilibrium moisture of $5.9 \%$ ) had a maximum methane holding capacity of $8.9 \mathrm{~cm}^{3} / \mathrm{g}(285 \mathrm{scf} / \mathrm{t})$. Similarly, the coal from the lower leaf at $1315.9 \mathrm{~m}$ (ash of $1.4 \%$ and equilibrium moisture of $5.7 \%$ ) had a greater maximum methane capacity $\left(12.2 \mathrm{~cm}^{3} / \mathrm{g}\right.$ or $\left.391 \mathrm{scf} / \mathrm{t}\right)$, which is a consequence of its very low ash and lower moisture contents. Based on measured gas content of $8.5 \mathrm{~cm}^{3} / \mathrm{g}$ for the upper leaf and $8.6 \mathrm{~cm}^{3} / \mathrm{g}$ for the lower leaf (see Section 3.4), the upper leaf is $96 \%$ gas saturated while the lower leaf is only $70.5 \%$ saturated. Characteristics that are influenced by oil generation in coals include methane moisture content, sorption capacity and gas content, and gas diffusion rate. It is likely that the presence of waxy oil in the coal structure has diminished the coal's capacity to sorb methane, which resulted in lower gas saturation in the lower leaf.

Gas components other than methane have discrete sorption rate behavior, which results in a time-dependent compositional fractionation if a binary or ternary gas adsorption isotherm were to be run. For a carbonaceous material such as coal, the atmospheric boiling point of a fluid is indicative of its relative adsorption strength on the coal surface. Thus, if the isotherm were to be conducted using a gas composition of $90 \%$ methane, $7 \%$ ethane, $1 \%$ propane and $1.5 \%$ carbon dioxide - which represent the desorbed gas composition (see Section 3.4.1.) the saturation at the reservoir pressure would be slightly higher. It is worth noting that the isotherm curve of the lower leaf coal sample is steeper at lower reservoir pressures, which indicates that small quantities of gas would desorb during pressure reduction in the early 
phases of the well production. Thus, greater depressurization would be required before most of the gas desorbs from the coal in the lower leaf.

\subsection{Reservoir properties}

\subsubsection{Porosity}

The coal matrix is porous but has very low permeability. Methane desorbs slowly from the matrix but rapidly through the cleat network (i.e., coal is essentially a fractured reservoir consisting having a dual porosity system). Measurements of porosity in coal vary depending on the measurement method used. Porosity decreases with rank through the bituminous rank series as a result of the combined effects of physical compaction and bituminization. A coal near the peak of the "oil window" normally has the lowest porosity because many of its pores are plugged by occluded oil (exsudatinite) ([Levine, 1993] and [Thomas and Damberger, 1976]). High oil coals have lower porosity. The Mannville coals in this study are in the lower part of the "oil window" and have occluded oil filling microcleats and small natural fractures. Although porosity measurements of the Mannville coals were not made in this study, it is expected that total porosity would be at least $5-6 \%$, as implied by the equilibrium moisture of the coals (see Section 3.2.2.).

\subsubsection{Permeability versus depth, stress regime and desorption rates}

Cleats play a greater role than bedding planes in controlling fluid flow in a coal seam. Coal core experiments in Japan (Li et al., 2004) have shown that specimens cored parallel to both the bedding plane and cleat strike had the highest permeability, even though the cleats were partly filled with calcite and clay minerals. The permeability in this direction was 2.5 times higher than perpendicular to the bedding plane and three times higher than in the direction parallel to the bedding plane but perpendicular to the cleat strike. Permeability in coal is strongly influenced by the in-situ stresses and it decreases exponentially with increasing depth.

Fig. 9 shows the relationship between absolute coal permeability versus depth for the Alberta Plains, based on publicly available data. Although there are numerous methods to estimate coal permeability, a long-term production test is considered to be more accurate. At $750 \mathrm{~m}$ (e.g., in the Norris area; Fig. 1), permeability in the Mannville coals based on long-term production was estimated to be about $7 \mathrm{mD}$ (Gentzis and Bolen, 2006). At about 1250$1300 \mathrm{~m}$ depth (e.g., in the Fenn area), permeability in the same coals decreases considerably and is in the $1-1.5 \mathrm{mD}$ range. Based on this figure, at $1000 \mathrm{~m}$ (e.g., in the Corbett Creek area), permeability in coal is expected to be in the 3-4 mD range (Gentzis and Bolen, 2006). Therefore, the 300-m vertical depth difference of the Mannville coals at Corbett Creek versus Fenn resulted in elevated in-situ stresses in the Fenn area, thus in lower coal permeability. The study by Bustin (1997) on coals from the Sydney Basin, Australia, has shown that the greatest stress sensitivity (reduction) in response to increasing effective stress occurs on coals that have low permeability. Since coal permeability at Fenn is lower than at Corbett Creek, it is expected that the Mannville coals at Fenn would be more sensitive to the in-situ stresses.

Factors such as cleat length, width, inter-connectivity and degree of mineralization as well as the amount of intergranular and phyteral porosity are important variables related to coal permeability, but are difficult to quantify. Maceral composition is an easy parameter to determine and has been shown to influence the way coal responds to stress increases. The 
brightest coals (vitrinite rich) are more fractured, have highest permeability, and are more sensitive to stress variations (Bustin, 1997). The higher permeability at Corbett Creek may be influenced not only by differences in coal maceral composition in the two areas but also by the more relaxed state of stress at Corbett Creek. The magnitude of in-situ stresses at the Mannville coal level further away from the deformation front at shallower depths are expected to be lower, which results in higher permeability, all other factors being equal. The regional study by Bell and Bachu (2003) shows a low vertical stress gradient salient - although not well developed - at the top of the Mannville Group in an area to the east of Corbett Creek in central Alberta, as a result of decreased compaction. The Corbett Creek area is also situated in a salient of low horizontal minimum stress gradient, although the number of data points is less than satisfactory. These low value salients should diagnose areas where permeability of coalbeds is likely to be higher. In the Fenn area, maximum principal stress orientation is $\mathrm{N} 63^{\circ} \mathrm{E}$, consistent with the regional pattern but slightly rotated. Vertical stress gradient is about $1.0 \mathrm{psi} / \mathrm{ft}(22-23 \mathrm{kPa} / \mathrm{m})$ at $1400 \mathrm{~m}$ depth, which reflects increased compaction as a result of burial depth. The minimum horizontal stress gradient ranges from $0.5-1.0 \mathrm{psi} / \mathrm{ft}(12-$ $22 \mathrm{kPa} / \mathrm{m}$ ), and the maximum horizontal stress gradient is expected to be $1.1-1.3 \times$ the minimum horizontal stress gradient (J. Cranstone, pers. commun., 2001).

The rate of gas desorption from the coal matrix is a critical parameter that can affect the early time gas production rate from a CBM reservoir. In general, the faster the gas desorption rate, the greater the early time gas production (Sawyer et al., 1987). However, long-term gas production is relatively insensitive to gas desorption rates (Reid et al., 1992). The Medicine River Seam in the Fenn area showed high desorption rates at reservoir temperature. The tau $(\tau)$ values or the time it takes for $63 \%$ of gas to desorb was only 2-6 h. In comparison, sorption times for Fruitland Formation coals in the San Juan Basin, USA, vary from 10 to $35 \mathrm{~h}$ at reservoir temperature whereas those in the Warrior Basin of Alabama are measured in weeks to even months. Desorption rates are faster in dull coals rich in inertinite macerals ([Crosdale et al., 1998] and [Laxminarayana and Crosdale, 1999]), such as the Mannville coals in this study.

\subsubsection{Cleating}

All permeability in coal is derived from the cleat network. Permeability is the most common limiting factor to economic CBM production. Cleat development and cleat density (spacing) are influenced by both coal rank and type. Cleat density is highest in bright lithotypes and, in low-rank coals, dull and banded dull lithotypes might not be cleated. In general, very low ash humic coals will be bright and have good cleat development. Rarely, very low ash coals (sapropelic) will be dull and have no cleating. Cleat density is highest in the rank of medium volatile bituminous to semiathracite (Law, 1993). Cleat orientation is typically related to basin tectonics. In the Alberta Basin, the major (face) cleats have formed parallel to the direction of maximum horizontal stress, which is roughly SW-NE. The butt cleats, when developed, are at almost $90^{\circ}$ to the face cleats.

Mannville coals show a strong azimuthal anisotropy in seismic data. The observed seismic anisotropy is the result of cleat development in the coals and the anisotropy varies within each coal seam, and from coal seam to coal seam within the same geographic area. This suggests that there is also significant variance in the permeability of Mannville coals in central Alberta. This is often the result of the proximity of the coal seam to paleo-high structures (Paleozoic carbonate reefs) and channels that represent incised valleys, and of the resulting differential compaction and extensional flexuring the coal is subjected to in areas off these structures. 
The Mannville coals in the Corbett Creek area exhibit good cleat development as the result of higher vitrinite content than the coals at Fenn. The Longford et al. HZ GNCOURTE well was drilled at 13-11-59-6W5 (Lat 54 $4^{\circ} \mathrm{N}$ and Long $114^{\circ} 9^{\prime} \mathrm{W}$ ) to true vertical depth of $1145 \mathrm{~m}$. A horizontal lateral was then drilled from the vertical well into the Upper Mannville coal seam to a length of $1289 \mathrm{~m}$. The lateral well encountered $1225 \mathrm{~m}$ of coal with good to excellent cleating and indications of reservoir permeability based on drilling fluid losses in the coal. Strong indications of gas were present throughout the drilling of the horizontal wellbore (Longford Corp. News Release, August 17, 2006).

In the Fenn area, the Mannville coals of high volatile C/B bituminous rank have average spacing between face cleats of about $1-1.5 \mathrm{~cm}$ whereas the distance between butt cleats (not well developed) is 3-4 cm. Face cleat spacing is in the anticipated range based on coal rank. For the Mannville coals at Fenn the face cleat spacing is $15 \mathrm{~mm}$ and the cleat aperture is 7.5 $10 \mu \mathrm{m}$ based on microscopic evidence. Based on a graph by Hughes and Levine (2002), the calculated permeability of the Mannville coals in this area is about $2-6 \mathrm{mD}$ (Fig. 10). This range is slightly higher than the permeability values calculated by the Alberta Research Council as part of a $\mathrm{N}_{2}$ and $\mathrm{CO}_{2}$ micro-pilot sequestration study in the Mannville coals at Fenn-Big Valley. Those values ranged from 1.2-3.6 mD (D. Law, pers. comm., 2002).

\subsubsection{Reservoir pressure and temperature}

Another possibility is that the Mannville coals at Corbett Creek are normally pressured (reservoir pressure is 655-724 psi (9500-10500 kPa) at $1000 \mathrm{~m}$ depth), compared to the coals at Fenn, which are significantly under-pressured (reservoir pressure is $655 \mathrm{psi}(9500 \mathrm{kPa})$ at $1300 \mathrm{~m}$ as a result of pressure depletion due to production of conventional hydrocarbons over many decades. Fig. 11 shows the variation of Mannville Formation pressure versus depth in

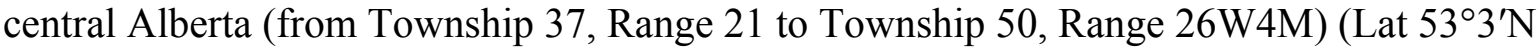
and Long $113^{\circ} 9^{\prime} \mathrm{W}$ ) reported in the public domain (Table 1). The Mannville Formation is under-pressured with respect to the freshwater gradient, in the intervals that contain oil, water and gas/water. Although the coal seam depth was similar $(\sim 1250 \mathrm{~m})$, coal pressures varied from 483-555 psi (7000-8050 kPa). The coals have lower pressure than other associated clastic facies, which indicates either distinct hydrological characteristics or an artifact of the testing method.

\subsection{Gas content and saturation}

Gas content in the Mannville coals, taken using conventional and wireline coring systems, increases with depth, although the gas content versus depth equation does not show a high correlation coefficient (Fig. 12). In the Oberlin 5-10-38-21W4 well, two coal samples were analyzed for reflectance and maceral composition. The average desorbed gas content in the upper leaf coal was $8.5 \mathrm{~cm}^{3} / \mathrm{g}(272 \mathrm{scf} / \mathrm{t})$ and of the lower leaf coal was $8.6 \mathrm{~cm}^{3} / \mathrm{g}(276 \mathrm{scf} / \mathrm{t})$. Average in-situ desorbed gas content was $233 \mathrm{scf} / \mathrm{t}\left(7.3 \mathrm{~cm}^{3} / \mathrm{g}\right)$ whereas the gas storage capacity at reservoir pressure $552 \mathrm{psi}(8 \mathrm{MPa})$ was $279 \mathrm{scf} / \mathrm{t}\left(8.7 \mathrm{~cm}^{3} / \mathrm{g}\right)$. Using a thickness of $10.25 \mathrm{~m}$ over two seams, the gas-in-place volume was estimated to be $106 \times 10^{6} \mathrm{~m}^{3} / \mathrm{km}^{2}$ or $9.7 \times 10^{9} \mathrm{scf} / \mathrm{mi}^{2}$ (Gunter et al., 2005). Since many of the vitrinite macerals in the Upper Medicine River Seam fluoresce, vitrinite reflectance values are likely suppressed, as has been demonstrated for the Mannville coals (Gentzis and Goodarzi, 1994). Suppression has been attributed to: (1) the impregnation of the vitrinitic matrix by bitumen generated under severe bacterial activity; and (2) the incorporation into the vitrinite structure of lipids derived from bacteria cell walls themselves ([Veld and Fermont, 1990], [Rathbone and Davis, 1993], 
[Goodarzi et al., 1994], [Suarez-Ruiz et al., 1994], [Perrussel et al., 1999] and [Iglesias et al., 2001]).

The unique petrological features shown by the Mannville coals at Corbett Creek, in terms of extra storage capacity in the telo-inertinite open cell lumens, may explain, in part, their higher gas content compared to Mannville coals of similar maturity and depth in the Fenn area. The Corbett Creek coals have gas content (lost plus desorbed gas only) that ranges from $6 \mathrm{~cm}^{3} / \mathrm{g}$ to $8 \mathrm{~cm}^{3} / \mathrm{g}(192-252 \mathrm{scf} / \mathrm{t})$ depending on ash content. Retrieval time of the core during the early coring process was $2 \mathrm{~h}$ (no wireline retrieval was used), which has most likely impacted the lost gas content. Higher gas content values (up to $11 \mathrm{~cm}^{3} / \mathrm{g}$ or $352 \mathrm{scf} / \mathrm{t}$, including residual gas) were also reported to the Alberta EUB, which suggests possible over-saturation with respect to methane. Carbonaceous shales ( $70 \%$ ash content) yielded only about $2 \mathrm{~cm}^{3} / \mathrm{g}$ (62 scf/ton), which is considerably lower than clean coal.

\subsubsection{Gas composition and isotopes}

Four desorption canister gas samples were taken from the Medicine River Seam at 5-10-38$21 \mathrm{~W} 4$; two from $1309 \mathrm{~m}$ and two from $1317 \mathrm{~m}$. The samples were taken about 10 days apart. The composition of $\mathrm{C}_{1}$ (methane) varied from $89.5-92.6 \%, \mathrm{C}_{2}$ (ethane) varied from 5.2-7.9\%, propane $\left(\mathrm{C}_{3}\right)$ from $0.1-1.5 \%$, and $\mathrm{CO}_{2}$ from $1-1.1 \%$. Methane content decreased within the sampling period at the expense of the heavier hydrocarbons. Heating value of the gas was 40 $41 \mathrm{MJ} / \mathrm{m}^{3}$ (moisture and acid-gas free basis) or 1074-1100 BTU/ $\mathrm{ft}^{3}$. Normally coal seam gas derived from low-maturity coals is "dry" (almost $99 \% \mathrm{C}_{1}$ ) and has a heating value of about 970-1000 BTU/ $/ \mathrm{ft}^{3}$. The higher heating value of the Mannville coal gas is the result of the increased concentration of "wet" gases, such as ethane and propane, which often happens in Cretaceous-age coals that are within the lower part of the "oil window" (Rice, 1993).

Based on public data, coal gas at Corbett Creek consisted of $94 \%$ methane, $0.7 \% \mathrm{CO}_{2}$, and $0.8 \% \mathrm{~N}_{2}$. Ethane and higher hydrocarbons were about $5 \%$. The heating value of the gas was $38-41 \mathrm{MJ} / \mathrm{m}^{3}$ (moisture and acid-gas free basis). The $\mathrm{CO}_{2}$ concentration increased over time to about $5 \%$ in one well, at the expense of methane. This is in agreement with the progressive enrichment of $\mathrm{CO}_{2}$ in the produced gas with time, which is seen in the San Juan Basin (Cui and Bustin, 2004). This compositional shift is in favor of higher $\mathrm{CO}_{2}$ concentrations in the production gas and is related to the higher effective diffusivity of $\mathrm{CO}_{2}$ through the coal matrix (the diffusivity rate of $\mathrm{CO}_{2}$ is about 30 times greater than of methane in coal). Due to the absence of magmatic intrusions in the Corbett Creek area, it is thought that the higher concentration of $\mathrm{CO}_{2}$ in the well may reflect the preferential desorption of methane as a result of higher coal permeability.

The onset of thermogenic hydrocarbon generation in coalbeds starts at \%Ro values of about $0.6 \%$. Thermogenic coalbed gases are characterized by: (1) common presence of heavier hydrocarbons $\left(\mathrm{C}_{2}+\right.$ values can be several percent or greater $)$ at intermediate ranks of high volatile and medium volatile bituminous coal; (2) enrichment of heavy isotope ${ }^{13} \mathrm{C}$ in methane and ethane with increasing rank (methane $\delta^{13} \mathrm{C}$ values more positive than - 55\% and ethane $\delta^{13} \mathrm{C}$ values more positive than $-33 \%$ ), and (3) enrichment of deuterium (methane $\delta \mathrm{D}$ values more positive than $-250 \%$ ). The $\%$ Ro of the Mannville coals at Fenn is about $0.6 \%$ (suppressed value). A Mannville coal well further north of the Fenn area (at 6-20-47-24W4) (Lat $53^{\circ} 0{ }^{\prime} \mathrm{N}$ and Long $113^{\circ} 7^{\prime} \mathrm{W}$ ) was analyzed for its $\delta^{13} \mathrm{C}$ and $\delta \mathrm{D}$ composition of methane. This well had a similar gas composition as the gas produced from the coals in the Fenn area and had $\delta^{13} \mathrm{C}$ of $-43.4 \%$, and $\delta \mathrm{D}$ of $-255 \%$. The reflectance and isotope values suggest a 
thermogenic origin of the coalbed gas at Fenn. The Mannville coals at Corbett Creek contain weakly fluorescing or hydrogen-poor vitrinite, which may explain the lower concentration of wet gases and/or condensate in the produced stream. No isotopic data from Corbett Creek was available.

Petrographic and geochemical studies have indicated that, at intermediate ranks (high volatile to medium volatile bituminous), sapropelic coals containing types I and II kerogen and hydrogen-rich fluorescing vitrinite generate both wet gas $\left(\mathrm{C}_{2}+\right.$ components $)$ and liquids (condensate). Conversely, humic coals (type III kerogen) generate dry gas (Rice, 1993). Hydrogen-rich (fluorescing) vitrinite is abundant in the coals at Fenn whereas the coals at Corbett Creek are rich in liptinite macerals, both of which are believed to be the source of the wet gas (gas that contains significant amounts of heavier hydrocarbons) and the condensate produced from the Fenn well.

\subsection{The role of horizontal drilling}

Commercial CBM production is currently taking place from the Mannville coals in Alberta despite the fact that the coals are in the lower part of the oil window. However, petrological composition, good cleat development, reasonable gas content, and permeability alone can not explain the high production rates from the Mannville coals. It is the application of horizontal and multilateral horizontal drilling technology that has made the difference between the very low production rates $\left(10-70 \mathrm{MCF} / \mathrm{D}\right.$ or 350 to $\left.2000 \mathrm{~m}^{3} / \mathrm{D}\right)$ in the early days of vertical development to the current situation, with rates exceeding $500 \mathrm{MCF} / \mathrm{D}\left(17,500 \mathrm{~m}^{3} / \mathrm{D}\right)$ per single horizontal well. The best known CBM producing basin in the world is the San Juan. Even in this basin, only the "fairway", where the coals are of high volatile A bituminous rank (\%Ro,max is 0.92$)$, produces at rates higher than $1 \mathrm{MMCF} / \mathrm{D}\left(27,000 \mathrm{~m}^{3} / \mathrm{D}\right)$. CBM production in the rest of the San Juan Basin averages only $100 \mathrm{MCF} / \mathrm{D}\left(3500 \mathrm{~m}^{3} / \mathrm{D}\right)$. The results demonstrate that it is not necessary to find another San Juan fairway in order to have a commercial CBM play. If the regional and local geological conditions allow it, horizontal multilateral drilling can substantially increase the CBM production rates and could result in the economic development of the resource.

\section{Summary and conclusions}

Mannville coals of similar rank present in two widely separated areas in Alberta that have experienced commercial CBM production (Fenn and Corbett Creek) were compared and contrasted. Differences in petrographic composition, reservoir pressure, in-situ stresses, and permeability are believed to be partly responsible not only for the gas content in the coals but also for both water and gas production rates reported from vertical fractured stimulated wells. The biggest impact on increased production was made by the recent application of horizontal drilling, particularly multiple horizontal drilling, in the Mannville coals.

\section{References}

Banerjee and Kalkreuth, 2002 I. Banerjee and W. Kalkreuth, Sedimentology, sequence stratigraphy, organic petrology, geochemistry, and palynology of Mannville group coals in south-central Alberta, Geol. Surv. Can. Bull. 571 (2002) 58 pp. 
Banerjee et al., 1994 I. Banerjee, W.D. Kalkreuth, E.H. Davies and K.C. Pratt, Sedimentology, palynology and coal petrology of Upper Mannville coal-bearing strata, central Alberta, Can. Soc. Petrol. Geol. Mannville Core Conf (1994), pp. 21-30.

Bell and Bachu, 2003 J.S. Bell and S. Bachu, In situ stress magnitude and orientation estimates for Cretaceous coal-bearing strata beneath the plains area of central and southern Alberta, Bull. Can. Pet. Geol. 51 (1) (2003), pp. 1-28.

Bustin, 1997 R.M. Bustin, Importance of fabric and composition on the stress sensitivity of. permeability in some coals, northern Sydney basin, Australia: relevance to coalbed methane exploitation, Am. Assoc. Pet. Geol. Bull. 81 (11) (1997), pp. 1894-1908.

Crosdale et al., 1998 P.J. Crosdale, B.B. Beamish and M. Valix, Coalbed methane sorption related to coal composition, Int. J. Coal Geol. 35 (1998), pp. 147-158.

Cui and Bustin, 2004 X. Cui and R.M. Bustin, Differential transport of $\mathrm{CO}_{2}$ and $\mathrm{CH}_{4}$ in coalbed aquifers: Implications for coalbed gas distribution and composition, Am. Assoc. Pet. Geol. Bull. 88 (8) (2004), pp. 1149-1162.

ERCB (Energy Resources Conservation Board) Reserves Report ST98, 2006 ERCB (Energy Resources Conservation Board) Reserves Report ST98 http://www.ercb.ca/docs/products/STs/st98-2006.pdf (2006).

Gentzis and Goodarzi, 1994 T. Gentzis and F. Goodarzi, Reflectance suppression in some Cretaceous coals from Alberta, Canada. In: P.K. Mukhopadhyay and W.G. Dow, Editors, Vitrinite reflectance as a maturity parameter: Applications and limitations, ACS Symp. Series vol. 570 (1994), pp. 93-110.

Gentzis and Bolen, 2006 T. Gentzis and D. Bolen, The role of horizontal wells in CBM development, 7th Annual Can. Soc. Unconvent. Gas Conf., Calgary, AB, Nov. 15-17 (2006).

Goodarzi et al., 1994 F. Goodarzi, L.R. Snowdon, T. Gentzis and D. Pearson, Chemical and petrological characteristics of liptinite-rich coals from Alberta, Canada, Mar. Pet. Geol. 11 (1994), pp. 307-319.

Gregor, 1997 V.A. Gregor, Mannville linears in the Lloydminster heavy oil area and their relationship to fractures and fluid flow in the Western Canada Sedimentary Basin. In: S.G. Pemberton and D.P. James, Editors, Petroleum Geology of the Cretaceous Mannville Group, Western Canada, Can. Soc. Petrol. Geol. Memoir vol. 18 (1997), pp. 428-474.

Gunter et al., 2005 W.D. Gunter, M.J. Mavor and J.R. Robinson, CO2 storage and enhanced methane production: Field testing at Fenn-Big Valley, Alberta, Canada, with applications, Proceedings of the 7th Int. Conf. on Greenhouse Gas Control Technologies (GHGT-7), September 5-9, 2004, Vancouver, Canada vol. 1 (2005), pp. 413-422.

Hughes and Levine, 2002 J.D. Hughes and J.R. Levine, Factors controlling coal seam gas production and Canada's CBM resource potential, Can. Institute's CBM Symp., Calgary, AB, June 17-18 (2002). 
Iglesias et al., 2001 I. Iglesias, M.J. Cuesta, F. Laggoun-Défarge and I. Suarez-Ruiz, The influence of impregnation by hydrocarbons on coal structure during its thermal evolution, $J$. Anal. Appl. Pyrolysis 58/59 (2001), pp. 841-871.

Law, 1993 B.E. Law, The relationship between coal rank and cleat spacing: implications for the prediction of permeability in coal: Proceedings of the 1993 Int. CBM Symp. Paper vol. 9341 (1993), pp. 435-442.

Laxminarayana and Crosdale, 1999 C. Laxminarayana and P.J. Crosdale, Role of coal type and rank on methane sorption characteristics of Bowen Basin, Australian coals, Int. J. Coal Geol. 40 (1999), pp. 309-326.

Levine, 1993 J.R. Levine, Coalification: the evolution of coal as source rock and reservoir rock for oil and gas. In: B.E. Law and D.D. Rice, Editors, Hydrocarbons from Coal, AAPG Studies in Geol. vol. 38 (1993), pp. 39-77.

Li et al., 2004 H. Li, S. Shimada and M. Zhang, Anisotropy of gas permeability associated with cleat pattern in a coal seam of the Kushiro coalfield in Japan, Environ. Geol. 47 (1) (2004), pp. 45-50.

Longford Corp. News Release, August 17, 2006 Longford Corp. News Release, August 17, 2006.

National Energy Board Report, 2006 National Energy Board Report http://www.nebone.gc.ca/energy/EnergyReports/EMAGasTDeliverabilityCanada2006_2008_e.pdf(2006).

Perrussel et al., 1999 B. Perrussel, F. Laggoun-Défarge, I. Suarez-Ruiz, A. Jimenez, M.J. Iglesias and J.N. Rouzaud, About some factors affecting vitrinite reflectance suppression. In: B.Q. Li and Z.Y. Liu, Editors, Prospects for Coal Science in the 21st Century, Shanxi Sci. and Techn. Press (1999), pp. 145-148.

Rathbone and Davis, 1993 R.F. Rathbone and D. Davis, The effects of depositional environment on vitrinite fluorescence intensity, Org. Geochem. 20 (1993), pp. 177-186.

Reid et al., 1992 G.W. Reid, B.F. Towler and H.G. Harris, Simulation and economics of coalbed methane production in the Powder River Basin, Paper 24360, Rocky Mountain Reg. Mtg, Casper, WY (1992), pp. 18-21 May.

Rice, 1993 D.D. Rice, Composition and origins of coalbed gas. In: B.E. Law and D.D. Rice, Editors, Hydrocarbons from Coal, AAPG Studies in Geol. vol. 38 (1993), pp. 159-184.

Ross and Eaton, 1999 G. Ross and D. Eaton, Basement reactivation in the Alberta Basin: observation and rationale, Bull. Can. Pet. Geol. 47 (1999), pp. 391-411.

Sawyer et al., 1987 W.K. Sawyer, M.D. Zuber, V.A. Kuuskraa and D.M. Horner, Using reservoir simulation and field data to define mechanisms controlling coalbed methane production, Proceedings, CBM Symp., Tuscaloosa, AL, Nov. 16-19 (1987), pp. 295-307.

Simpson, 2005 M. Simpson, The Corbett CBM field: an emerging giant gas field?, 6th Annual Can. Soc. Unconvent. Gas Conf., Calgary, AB, Nov. 8-10 (2005). 
Stasiuk et al., 2002 L.D. Stasiuk, M.G. Fowler and G. Addison, Thermal maturity evaluation of Lower Cretaceous Mannville Group and equivalent coals in the Western Canada Sedimentary Basin: a compilation of vitrinite reflectance data, Geol. Surv. Can. 4342 (2002) Open File.

Suarez-Ruiz et al., 1994 I. Suarez-Ruiz, M.J. Iglesias, A. Jimenez, F. Laggoun-Défarge and J.G. Prado, Petrographic and geochemical anomalies detected in Spanish Jurassic jet. In: P.K. Mukhopadhyay and W.G. Dow, Editors, Vitrinite reflectance as a maturity parameter, Applications and limitations, ACS Symp. Series vol. 570 (1994), pp. 76-92.

Thomas and Damberger, 1976 J. Thomas Jr. and H.H. Damberger, Internal surface area, moisture content, and porosity of Illinois coals: variations with coal rank: Illinois State, Geol. Surv. Circ. 493 (1976) 38 pp.

Veld and Fermont, 1990 H. Veld and W.J.J. Fermont, The effect of a marine transgression on vitrinite reflectance values. In: Mededelingen Rijks Geologische Dienst. In: W.J.J. Fermont and J.W. Weegink, Editors, Int. Symp. on Org. Petrol. vol. 45 (1990), pp. 151-169.

Wadsworth et al., 2002 J. Wadsworth, C. Diessel, R. Boyd, D. Leckie and B.A. Zaitlin, Stratigraphic style of coal and non-marine strata in a tectonically influenced intermediate accommodation setting: the Mannville Group of the Western Canadian Sedimentary Basin, south-central Alberta, Bull. Can. Pet. Geol. 50 (4) (2002), pp. 507-541. 
Figures and Table

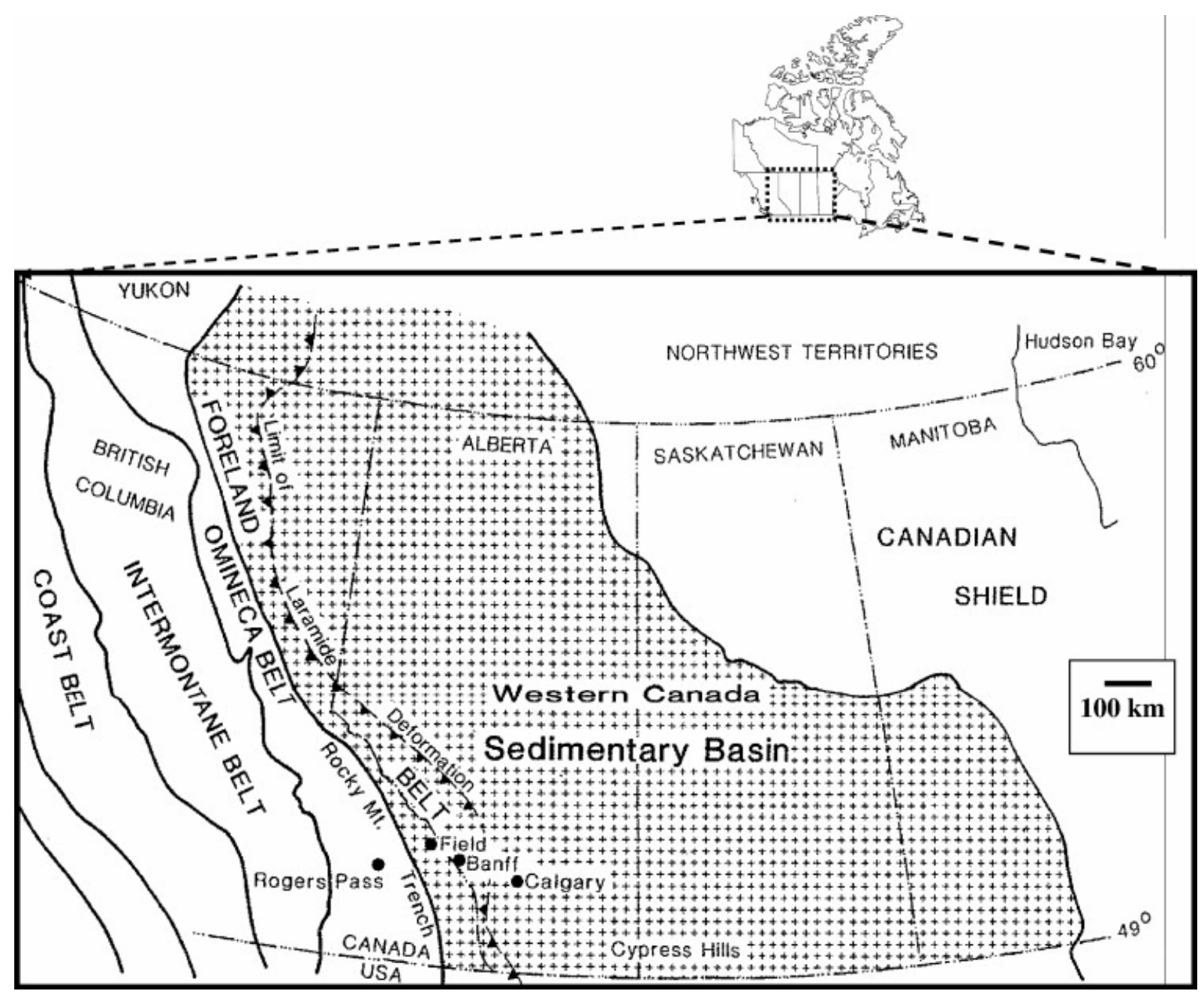

Fig. 1. The outline of the Western Canada Sedimentary Basin (WCSB). 

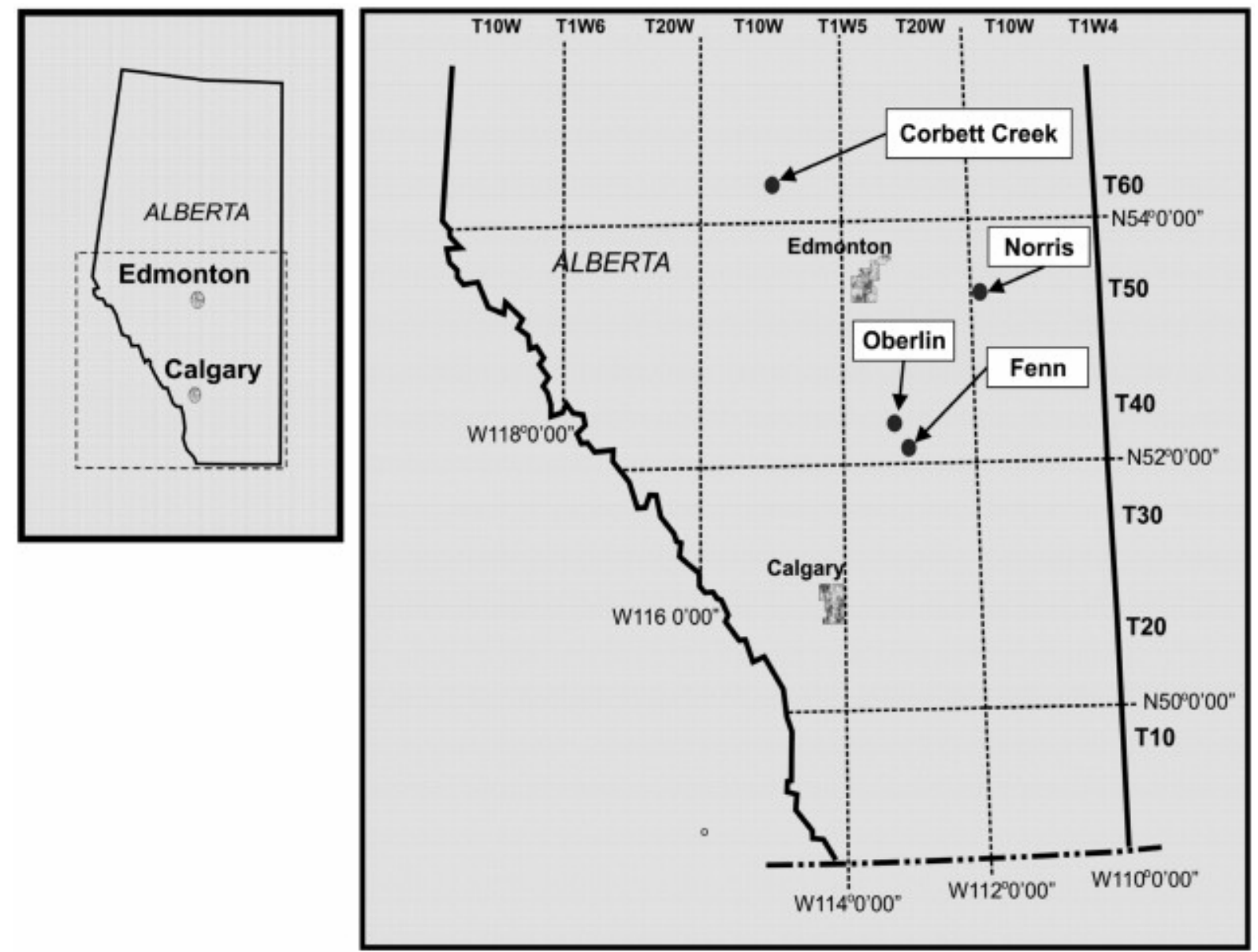

Fig. 2. Map of Alberta showing the two comparative areas, Fenn-Big Valley and Corbett Creek, as well as the Norris area. 
A

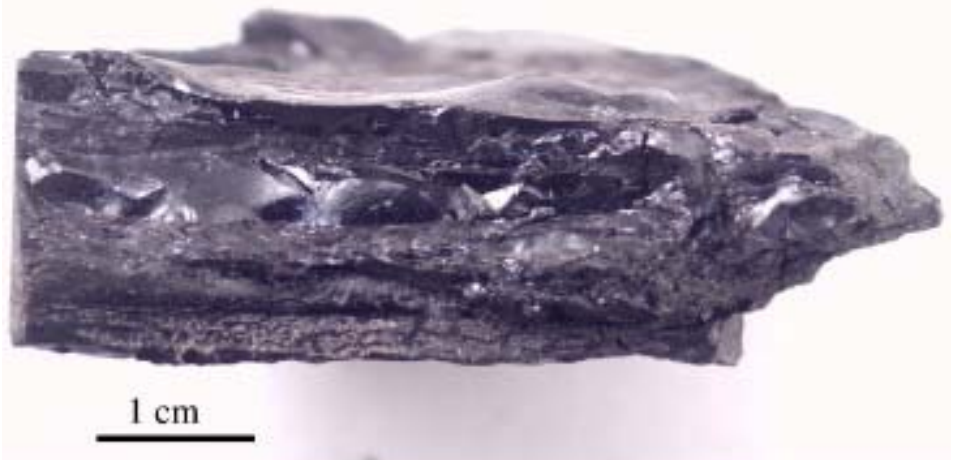

B

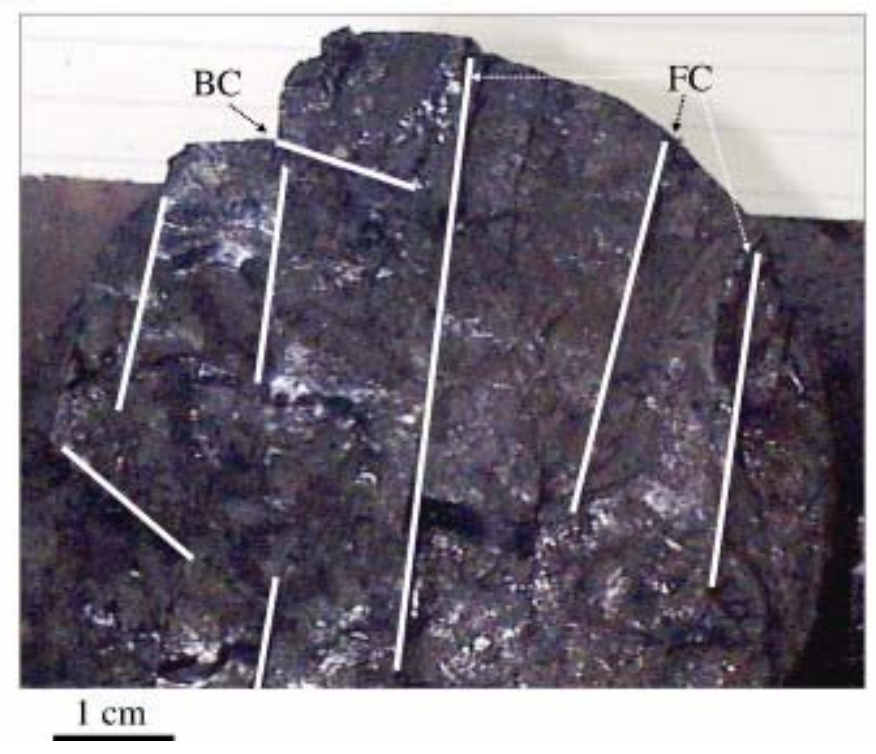

Fig. 3. (A) Hand-specimen of Mannville coal from the Fenn-Big Valley area showing distinct bright and semi-bright to dull banding; (B) Another specimen showing face cleat (FC) and butt cleat $(\mathrm{BC})$ development and conchoidal fracture pattern of the vitrinite-rich layers. Scale bar shown at the bottom is $1 \mathrm{~cm}$. Photo 3B is courtesy of Dr. David Marchioni of Calgary, Alberta. 

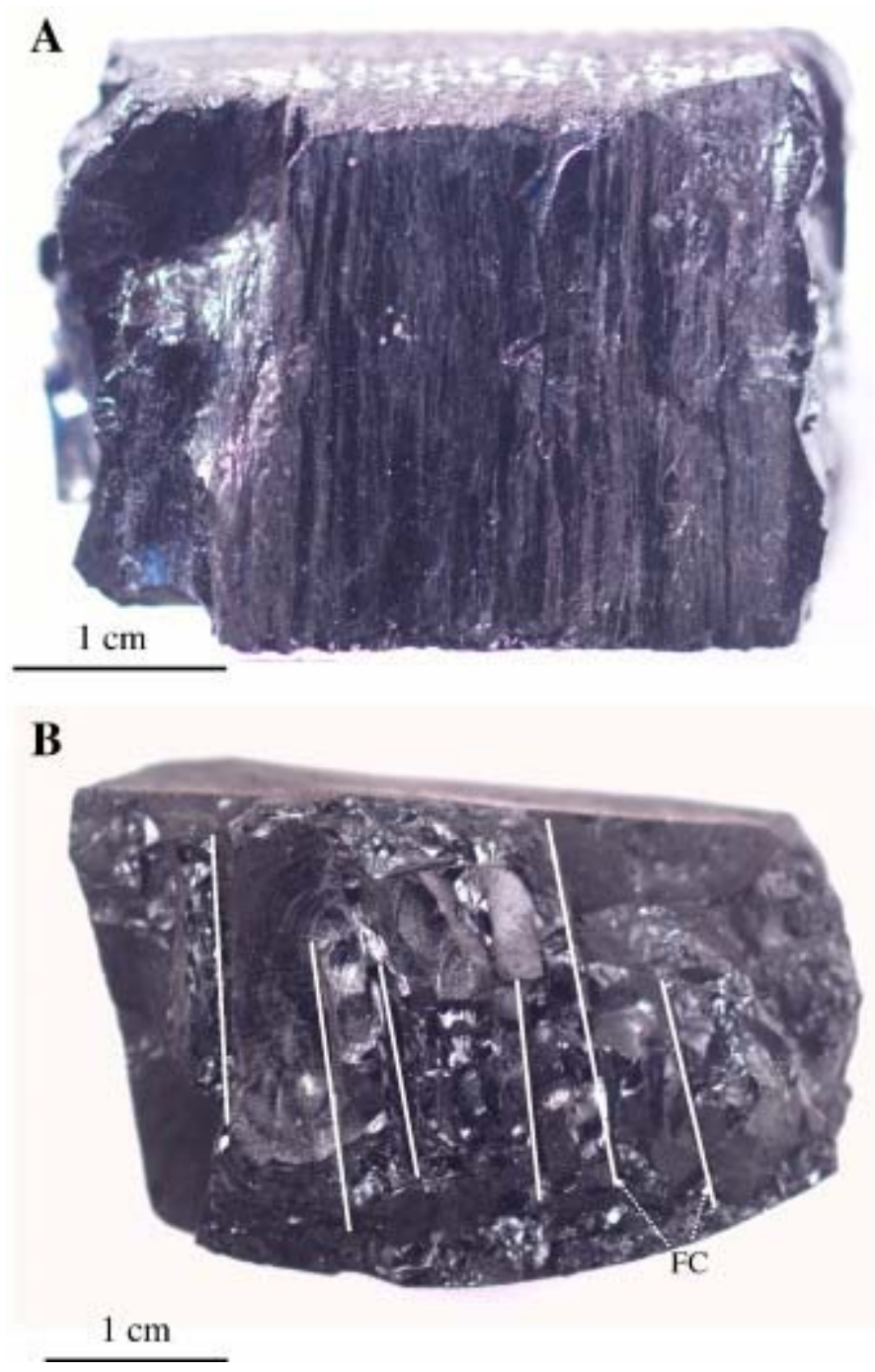

Fig. 4. Coal block from the Corbett Creek area showing alternating mainly bright to semibright lithotypes (A); Core showing development of face cleats (FC) with narrow spacing $(\sim 0.5 \mathrm{~cm})$ and short, discontinuous butt cleats $(\mathrm{B})$. Scale bar is $1 \mathrm{~cm}$. 

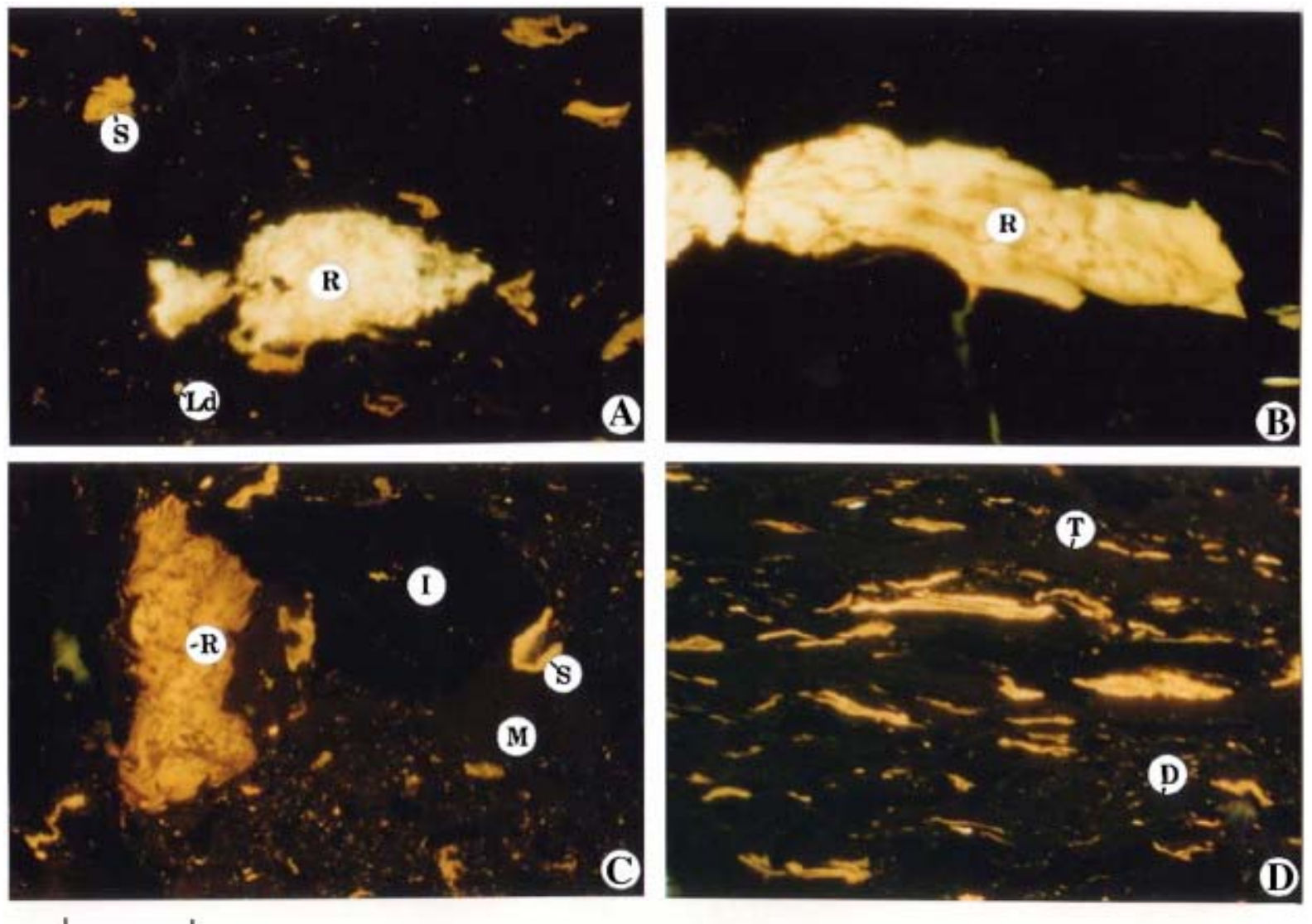

Fig. 5. Photomicrographs of the Upper Medicine River Seam (UMR) at 1258.8-1263.1 m, well 5-23-36-20W4 in the Fenn area under fluorescent light. The bar at the bottom left is $40 \mu \mathrm{m}$ long. (A): Resinite (R), sporinite (S) and liptodetrinite (Ld) in a weakly fluorescing desmocollinite matrix; (B) Massive resinite (R) in non-fluorescing vitrinite; (C): Weathered resinite (R), sporinite (S) and angular inertinite (I) in a fluorescing desmocollinite matrix; (D): Fluorescing collotelinite (T) and non-fluorescing desmocollinite (D). 

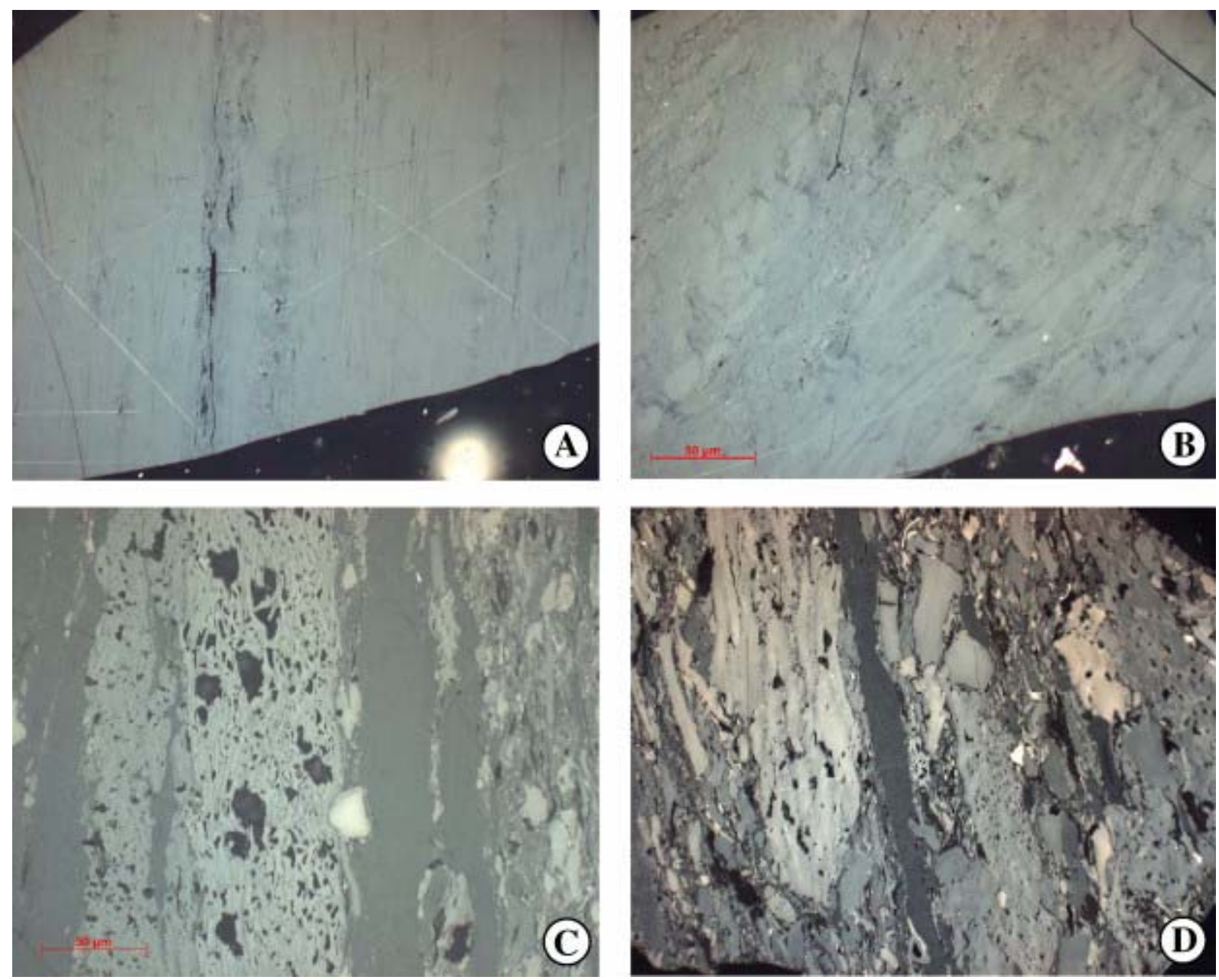

Fig. 6. Photomicrographs of the Upper Medicine River Seam (UMR) at 1258.8-1263.1 m, well 5-23-36-20W4 in the Fenn area. The scale is shown at the bottom left. (A): Telinite showing remnant cell structure; (B): Telinite with oval corpocollinite; (C) Trimacerite containing thick telocollinite bands, desmocollinite, sporinite, fusinite, semifusinite and inertodetrinite; (D) Trimacerite containing semifusinite, fusinite, macrinite, inertodetrinite, sporinite and telocollinite. 

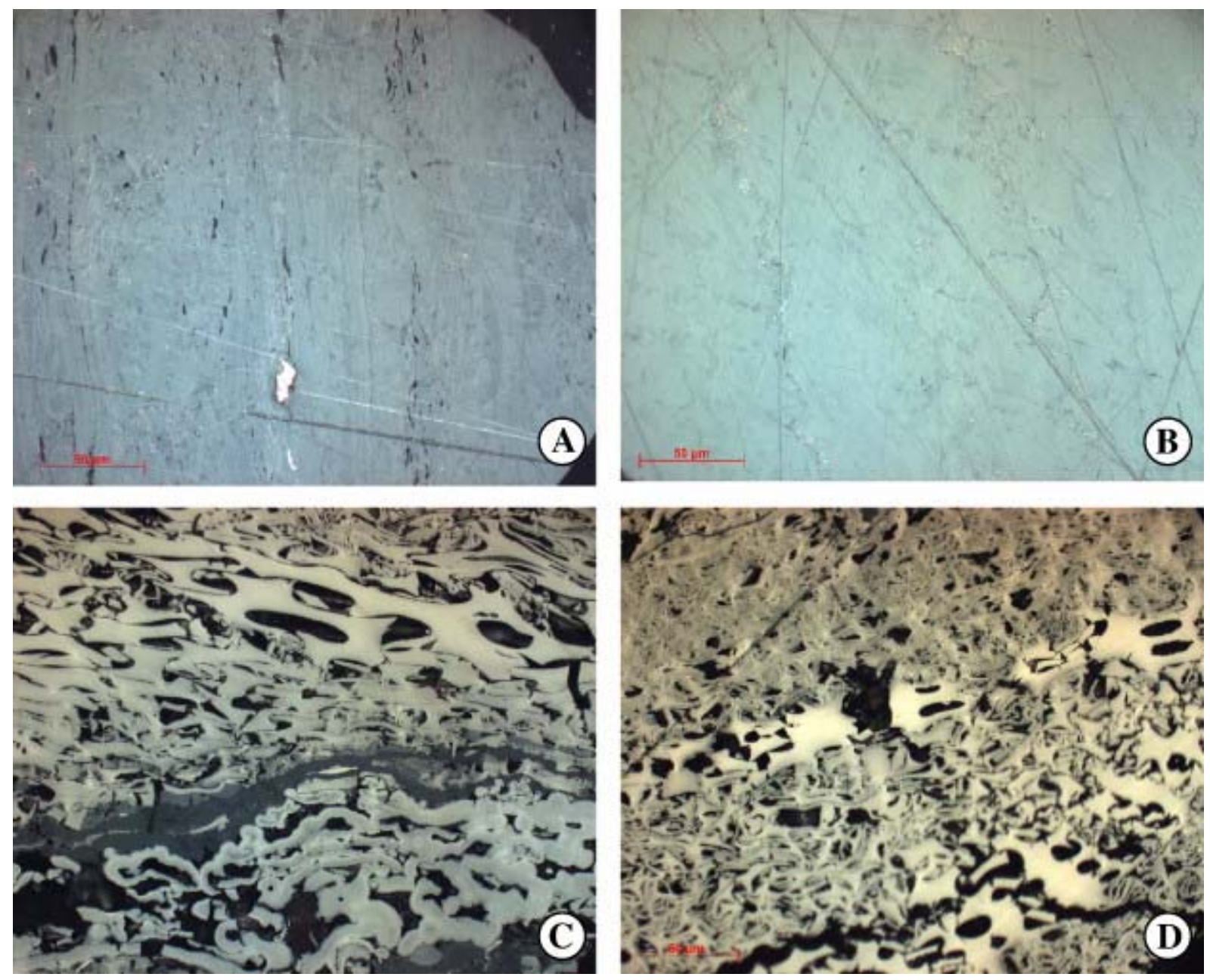

Fig. 7. Photomicrographs of the Main Seam at $1095 \mathrm{~m}$, well 2-21-60-6W5 (Lat $54^{\circ} 3^{\prime} \mathrm{N}$ and Long $114^{\circ} 9^{\prime} \mathrm{W}$ ), Corbett Creek area, under white light. The bar length is $50 \mu \mathrm{m}$. (A) Telinite showing faint cell structure containing dark oval bodies of resinite and inertodetrinite; (B) More compressed telinite containing oval corpocollinite; (C) Fusinite with sieve and bogen structure; (D) Similar to (C). 

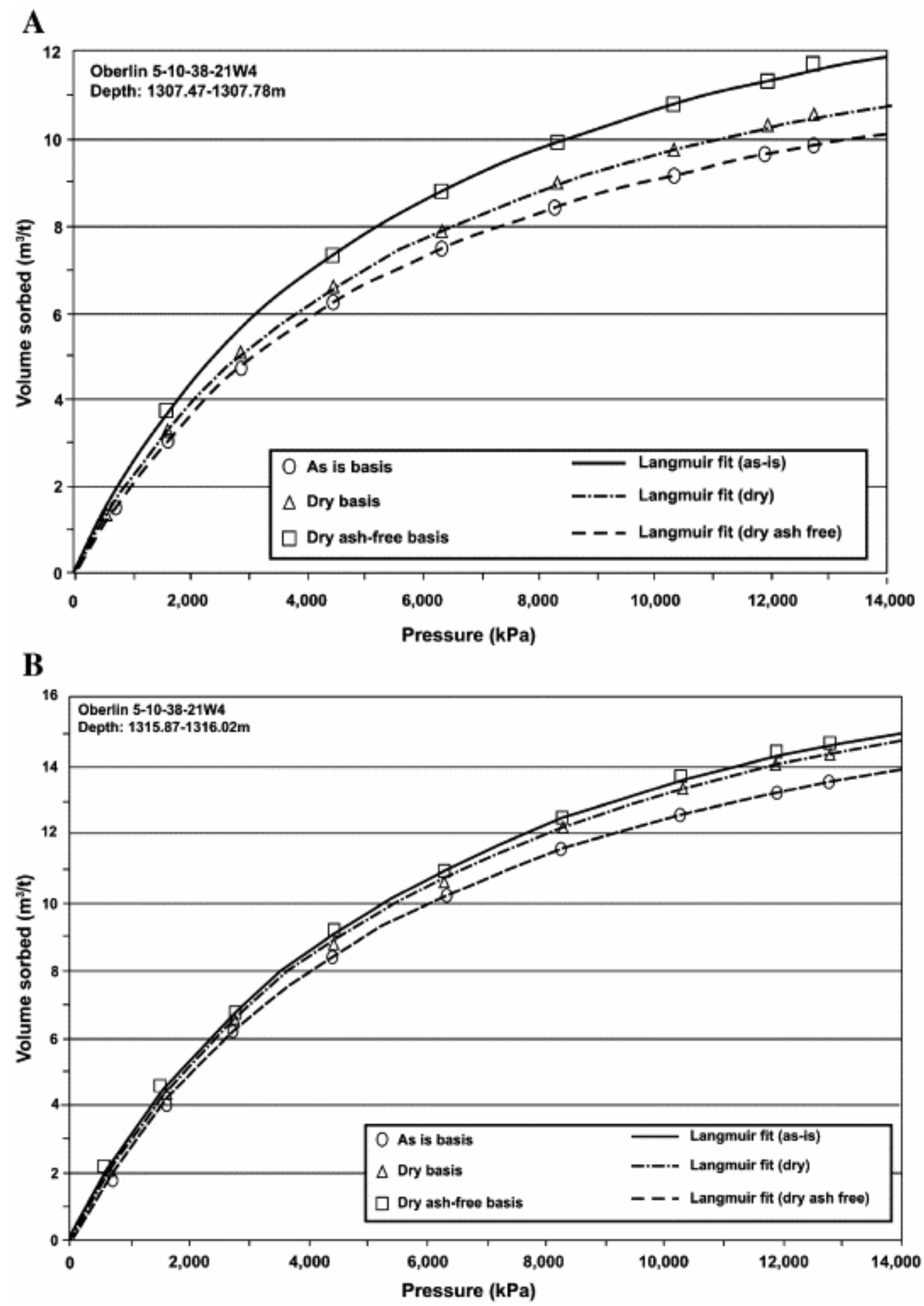

Fig. 8. High-pressure methane adsorption isotherm of the upper leaf, Medicine River Seam at $1307.47 \mathrm{~m}$ (A); adsorption isotherm of the lower leaf, Medicine River coal seam at 1315.87$1316.02 \mathrm{~m}(\mathrm{~B})$; Well 5-10-38-21W4, (Lat 52.3 ${ }^{\circ} \mathrm{N}$ and Long $113.05^{\circ} \mathrm{W}$ ), Fenn-Big-Valley area. 


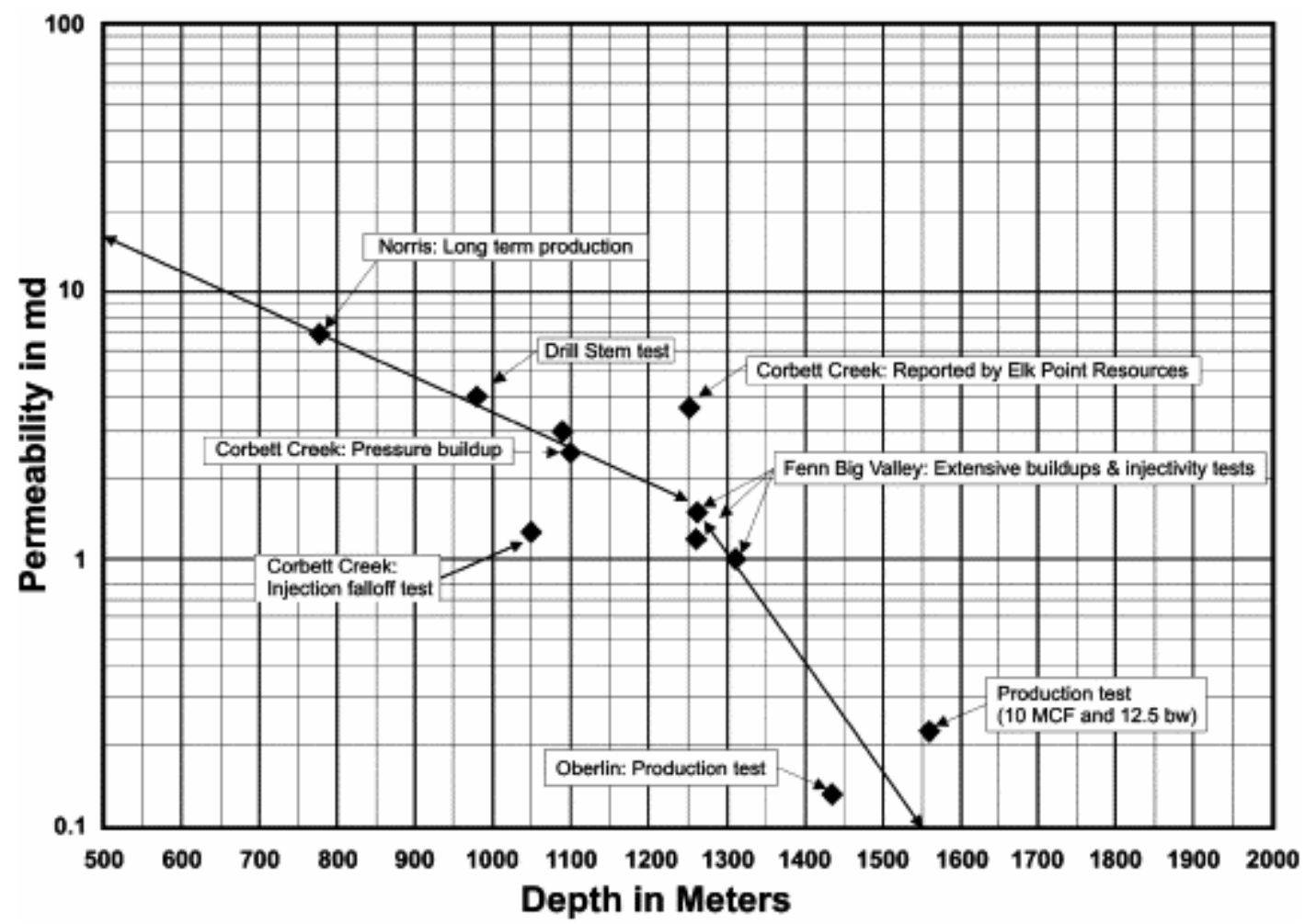

Fig. 9. Variation of absolute permeability of Mannville coals versus depth in the Alberta Plains. Note the different methods used to estimate coal permeability and the inflection point at about $1250 \mathrm{~m}$, which suggests a dramatic decrease in permeability beyond that depth.

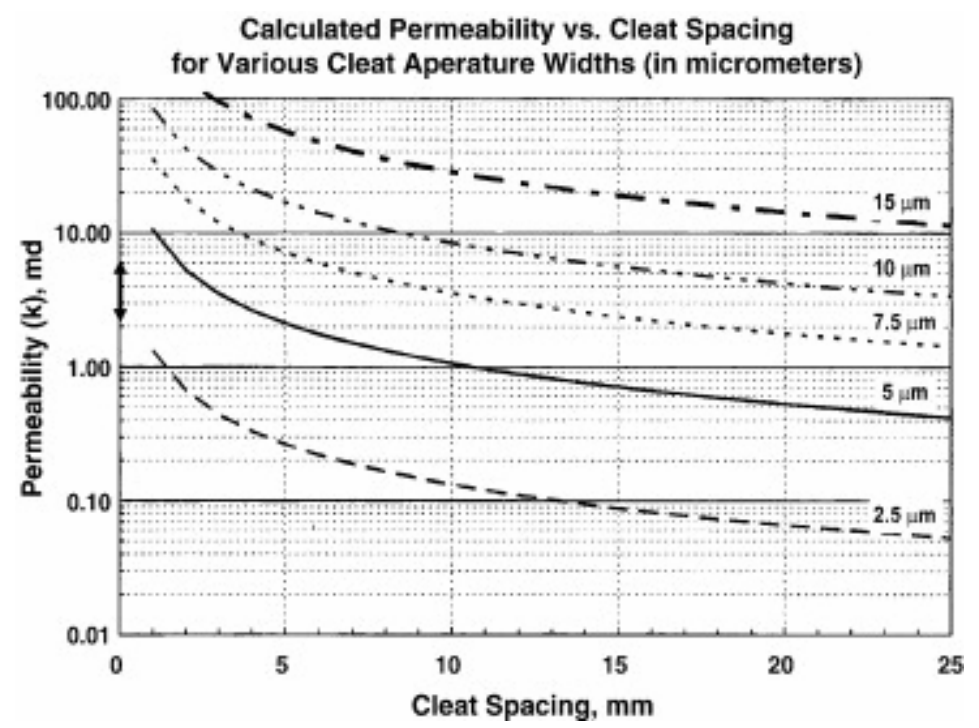

Fig. 10. Calculated permeability of the Mannville coals at Fenn, based on face cleat spacing and cleat aperture (from Hughes and Levine, 2002). 


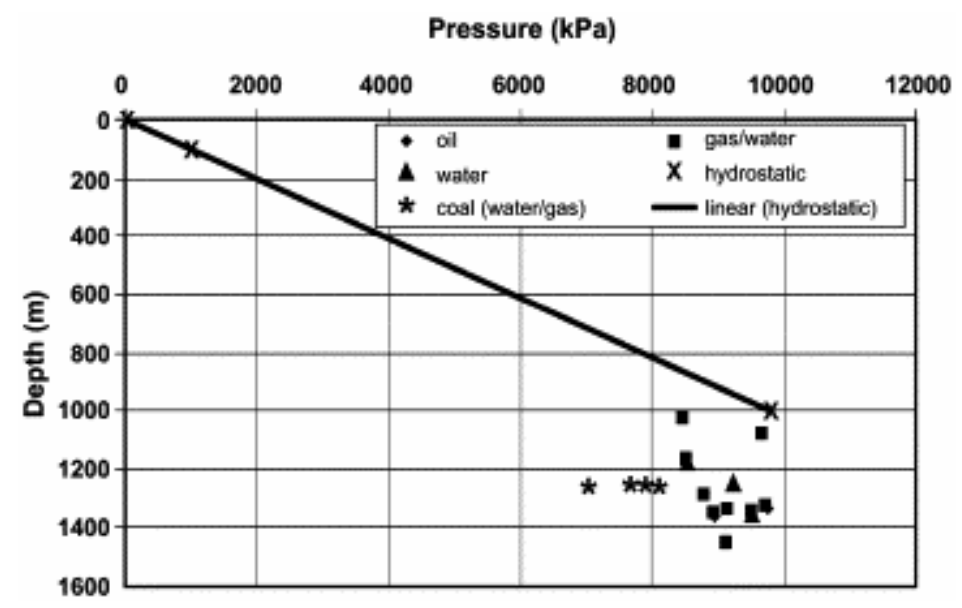

Fig. 11. Variation of Mannville Formation pressure versus depth in central Alberta.

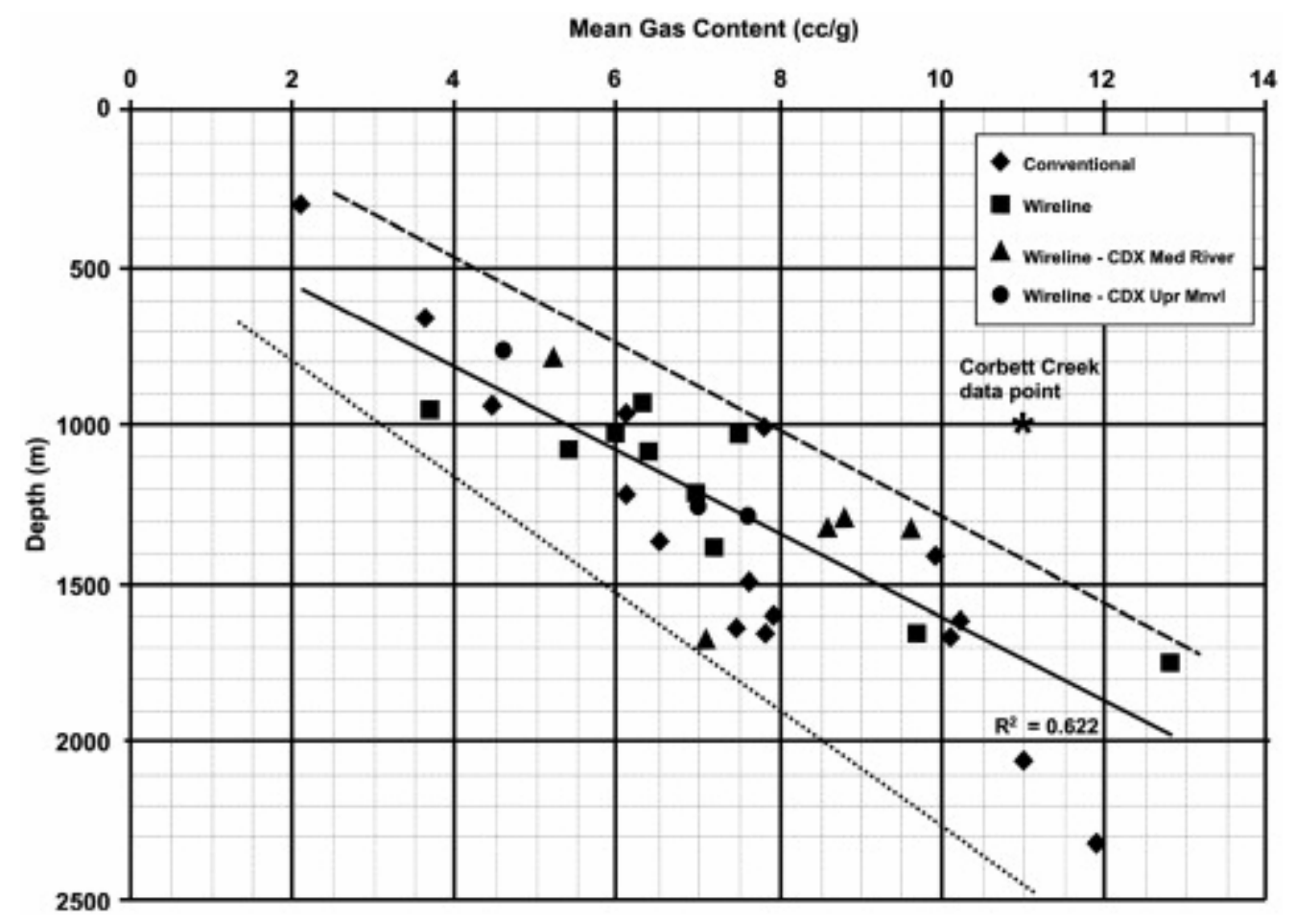

Fig. 12. Variation of gas content versus depth for Mannville coals taken using conventional and wireline coring systems. 
Table 1. : Pressure data in Mannville coal seams and associated facies, central Alberta Plains (Alberta EUB public records)

\begin{tabular}{|c|c|c|c|c|c|c|c|c|c|c|c|}
\hline Location & $\begin{array}{l}\text { Test } \\
\text { type }\end{array}$ & $\begin{array}{l}\text { Total } \\
\text { depth }\end{array}$ & $\begin{array}{l}\text { Test } \\
\text { date }\end{array}$ & Formation & $\begin{array}{l}\text { Interval } \\
\text { from }\end{array}$ & $\begin{array}{l}\text { Interval } \\
\text { to }\end{array}$ & $\begin{array}{l}\text { KB } \\
\text { elev }\end{array}$ & $\begin{array}{l}\text { Recorder } \\
\text { depth }\end{array}$ & $\begin{array}{l}\text { Maximum } \\
\text { pressure }\end{array}$ & $\begin{array}{l}\text { Initial } \\
\text { hydrostatic }\end{array}$ & $\begin{array}{l}\text { Final } \\
\text { hydrostatic }\end{array}$ \\
\hline $\begin{array}{l}102 / 13-6-045- \\
21 \mathrm{~W} 4 / 00\end{array}$ & INF & 1528 & $\begin{array}{l}\text { 13- } \\
\text { Nov- } 88\end{array}$ & MNVL & 1329 & 1333 & 760.9 & 1331.5 & 9738.5 & 15,143 & 15,063 \\
\hline $\begin{array}{l}\text { 100/07-10-046- } \\
26 \mathrm{~W} 4 / 00\end{array}$ & INF & 1563 & $\begin{array}{l}\text { 7-Aug- } \\
88\end{array}$ & MNVL & 1353 & 1357.5 & 812.5 & 1355.9 & 8930 & 15,214 & 14,992 \\
\hline $\begin{array}{l}100 / 09-23-44- \\
22 \mathrm{~W} 4 / 00\end{array}$ & INF & 1620 & $\begin{array}{l}25-\text { Jun- } \\
86\end{array}$ & MNVL & 1349 & 1355 & 810 & 1351 & 9506 & 15,436 & 15,298 \\
\hline $\begin{array}{l}\text { 100/04-36-045- } \\
26 \mathrm{~W} 4 / 00\end{array}$ & INF CC & 1565 & $\begin{array}{l}\text { 7-Jun- } \\
99\end{array}$ & MNVL & 1335 & 1345 & 798 & 1337.9 & 9127 & $15,036.5$ & $14,925.4$ \\
\hline $\begin{array}{l}100 / 06-10-046- \\
23 \mathrm{~W} 4 / 00\end{array}$ & MINF & 1410 & $\begin{array}{l}\text { 7-Jun- } \\
94\end{array}$ & MNVL & 1286.5 & 1291 & 758 & 1289.3 & 8787.9 & 14,339 & 13,947 \\
\hline $\begin{array}{l}100 / 02-04-050- \\
21 \mathrm{~W} 4 / 00\end{array}$ & INF & 1342 & $\begin{array}{l}3-\text { Feb- } \\
81\end{array}$ & MNVL & 1024 & 1040 & 761.3 & 1026 & 8467.3 & 11,831 & 11,620 \\
\hline $\begin{array}{l}100 / 04-16-050- \\
23 \mathrm{~W} 4 / 00\end{array}$ & INF & 1336 & $\begin{array}{l}28- \\
\text { Aug-97 }\end{array}$ & MNVL & 1075 & 1086 & 736 & 1077.6 & 9663.2 & 11,724 & 11,656 \\
\hline $\begin{array}{l}100 / 15-36-050- \\
24 \mathrm{~W} 4 / 00\end{array}$ & MINF & 1300 & $\begin{array}{l}11-J u l- \\
89\end{array}$ & MNVL & 1174 & 1187 & 734.2 & 1176 & 8479.3 & 13,683 & 13,548 \\
\hline $\begin{array}{l}100 / 15-36-050- \\
24 W 4 / 00\end{array}$ & MINF & 1300 & $\begin{array}{l}11-\text {-Jul- } \\
89\end{array}$ & MNVL & 1169 & 1182 & 734.2 & 1171 & 8527.1 & 13,568 & 13,438 \\
\hline
\end{tabular}




\begin{tabular}{|l|l|l|l|l|l|l|l|l|l|l|l|}
\hline Location & $\begin{array}{l}\text { Test } \\
\text { type }\end{array}$ & $\begin{array}{l}\text { Total } \\
\text { depth }\end{array}$ & $\begin{array}{l}\text { Test } \\
\text { date }\end{array}$ & Formation & $\begin{array}{l}\text { Interval } \\
\text { from }\end{array}$ & $\begin{array}{l}\text { Interval } \\
\text { to }\end{array}$ & $\begin{array}{l}\text { KB } \\
\text { elev }\end{array}$ & $\begin{array}{l}\text { Recorder } \\
\text { depth }\end{array}$ & $\begin{array}{l}\text { Maximum } \\
\text { pressure }\end{array}$ & $\begin{array}{l}\text { Initial } \\
\text { hydrostatic }\end{array}$ & $\begin{array}{l}\text { Final } \\
\text { hydrostatic }\end{array}$ \\
\hline $\begin{array}{l}100 / 09-23-044- \\
22 \text { W4/00 }\end{array}$ & INF & 1620 & $\begin{array}{l}25-J u n- \\
86\end{array}$ & MNVL & 1349 & 1355 & 810 & 1351 & 9506 & 15,436 & 15,298 \\
\hline $\begin{array}{l}100 / 11-31-048- \\
22 \text { W4/00 }\end{array}$ & INF & 1356.7 & $\begin{array}{l}30-J u l- \\
77\end{array}$ & MNVL & 1247.9 & 1251.5 & 756.8 & 1249.7 & 9225.2 & 14,610 & $14,161.8$ \\
\hline $\begin{array}{l}100 / 15-36-050- \\
24 W / 00\end{array}$ & MINF & 1300 & $\begin{array}{l}11-J u n- \\
89\end{array}$ & MNVL & 1174 & 1187 & 734.2 & 1176 & 8479.3 & 13,683 & 13,548 \\
\hline $\begin{array}{l}100 / 15-36-050- \\
24 W 4 / 00\end{array}$ & MINF & 1300 & $\begin{array}{l}11-J u l- \\
89\end{array}$ & MNVL & 1169 & 1182 & 734.2 & 1171 & 8527.1 & 13,568 & 13,438 \\
\hline
\end{tabular}


